\title{
Rodent Models of Painful Diabetic Neuropathy: What Can We Learn from Them?
}

\author{
Anne-Sophie Wattiez ${ }^{1,2 \#}$, David André Barrière ${ }^{1,2^{*}}$, Amandine Dupuis $^{1,2}$ and Christine Courteix ${ }^{1,2}$ \\ ${ }^{1}$ Clermont Université, Université d'Auvergne, Pharmacologie Fondamentale et Clinique de la Douleur, France \\ ${ }^{2}$ Inserm, U 1107, Neuro-Dol, F-63001 Clermont-Ferrand, France \\ \#Equal Contribution
}

\begin{abstract}
Diabetic peripheral neuropathy (DPN) is the most common clinical complication of diabetes mellitus, and can be related to type 1 as well as type 2 . To date, this highly invalidating neurological impairment is insufficiently known, understood and the treatments proposed by physicians are still empirical and poorly efficient.

Animal rodent modeling of clinical DPN offers a powerful tool in order to understand diabetes-mediated peripheral nerve injury. The majority of studies which have investigated DPN in rodent used the streptozotocin-induced rat model which reproduces metabolic lesional mechanisms of Type 1 Diabetes Mellitus (T1DM) and usual symptoms of evoked pain. Although the clinical relevance of this model is challenged due to 1) a high prevalence of type 2compared to type 1-diabetes in the adult population, 2) the important alteration of the general clinical state of the animals and 3) the lack of morphological changes in peripheral nerves, many studies have contributed to a better pathophysiological and pharmacological understanding of the DPN.

In this review we investigated rodent models of T1DM and T2DM, their contributions for a better understanding of DPN, molecular targets and pharmacological strategies, which could be used for the enhancement of clinical care. Finally, we proposed possible ways to improve animal modeling.
\end{abstract}

\section{Introduction}

Neuropathic pain has recently been redefined by the Neuropathic Pain Special Interest Group (NeuPSIG) to correspond to "pain initiated or caused by a primary lesion or dysfunction in the nervous system" [1]. Its prevalence in general population, all causes combined, is estimated at 1.5 [2] and $6.9 \%$ [3]. The development of experimental models of neuropathic pain secondary to lesions of traumatic origin (constriction, partial section, infraorbital nerve ligation, spinal nerve ligation [4-6], etc), metabolic (diabetes, [7]) or toxic (anticancer agent [8] or retroviral [9]) has contributed to a better understanding of their pathophysiology. These models try to stand as close as possible to the symptomatology and / or clinical etiopathogeny of neuropathic pain and are currently used to evaluate new therapeutic drugs.

The need for modeling diabetic neuropathic pain comes from a clinical reality: diabetes is one of the largest providers of neuropathy in the world. Indeed, of 246 million diabetic patients, between 20 and 30 million are affected by symptomatic diabetic neuropathy [10]. Neuropathy occurs for both type 1 diabetes mellitus (T1DM) and type 2 diabetes mellitus (T2DM), suggesting that hyperglycemia is the primary etiologic factor [11]. The most frequent clinical form is by far the diabetic distal sensory or sensorimotor polyneuropathy, affecting $30 \%$ of community-based people with diabetes [12]. Sensory polyneuropathy presents a typical distribution "in stocking and glove", and can sometimes be asymptomatic but usually causes abnormal sensations (paresthesia and dysesthesia) and/or pain. Here, the longest fibers are first affected, which explains the distal distribution. Continuous or intermittent, spontaneous or evoked, pain and abnormal sensations precede or accompany the neuropathy. Estimated prevalence of painful polyneuropathy varies between 8 and 65\% [13-16] according to studies and the diagnostic tools used. Indeed, using the DN4 pain questionnaire, an overall prevalence of painful diabetic peripheral neuropathy of $14 \%$ [17] or $65.3 \%$ [14] was found. By using the Michigan Neuropathy
Screening Instrument (MNSI) and questions from the Brief Pain Inventory (BPI), the prevalence rate of painful diabetic peripheral neuropathy was $8 \%$ (MNSI score of 7 or higher and a $24 \mathrm{~h}$ average pain rating BPI greater than 0) [16]. Just like neuropathic pain of other etiology, diabetic neuropathic pain responds poorly to classical analgesics (acetaminophen, NSAIDs) and the reference treatments are only partially effective. Three molecules have specific authorization in this indication: gabapentin and pregabalin, calcium channels $\alpha_{2} \delta$ subunit ligands, and duloxetine, a serotonin and norepinephrine reuptake inhibitor (SNRI).

From these clinical settings, experimental rodent models of spontaneous diabetes were developed (Type 1 diabetic insulinopenic BB / Worchester Rats, type 2 diabetic hyperinsulinemic BBZDR / Worchester Rats, NOD Mice, LETL Rats, Akita Mice spontaneous type 1 diabetes [B6Ins2(Akita)]) or obtained by dietary manipulations (overeating, fasting, shift from a high fat diet to a high carbohydrate diet) (High-fat diet-fed Mice), genetic manipulations (Zucker diabetic fatty rat, Obese leptin-deficient ( ob / ob) Mice, Leptin receptor deficient ( $d b / d b)$ Mice, nonobese diabetic Mice) or chemo-induced pancreatic toxicity (streptozotocin (STZ), alloxan (ALX)) [18,19].

*Corresponding author: David André Barrière, Clermont Université, Universite d'Auvergne, Pharmacologie Fondamentale et Clinique de la Douleur, BP 10448 F-63000 Clermont-Ferrand, France, Tel: 0033473278230 ; Fax: 0033473274 621; E-mail: david.barriere@u-clermont1.fr

Received April 02, 2012; Accepted May 26, 2012; Published May 29, 2012

Citation: Wattiez AS, Barrière DA, Dupuis A, Courteix C (2012) Rodent Models of Painful Diabetic Neuropathy: What Can We Learn from Them? J Diabetes Metab S5:008. doi:10.4172/2155-6156.S5-008

Copyright: (c) 2012 Wattiez AS, et al. This is an open-access article distributed under the terms of the Creative Commons Attribution License, which permits unrestricted use, distribution, and reproduction in any medium, provided the original author and source are credited. 


\section{Experimental Models of T1DM Induced by Chemical Pancreatectomy in Rats}

Two agents can be used to induce chemical pancreatectomy, both are glucose analogs: ALX, a pyrimidine derivative (synthesized in 1938) and STZ, an alkylating and antimicrobial agent. Chemical properties of these compounds are crucial for their ability to induce diabetes [20]. Both are hydrophilic and cannot cross plasma membrane. They use the glucose transporter GLUT2, which is expressed by the pancreatic betacells.

Cytotoxic effects of ALX are due to its reduced reaction product, dialuric acid, and to the production of reactive oxygen species (ROS) (superoxide radicals $\mathrm{O}_{2}^{\circ}$-, hydrogen peroxide $\mathrm{H}_{2} \mathrm{O}_{2}$ and hydroxyl $\mathrm{OH}^{\circ}$, [21]).

STZ exerts its toxicity through DNA alkylation [21]. Protein glycosylation is an additional deleterious factor. STZ induces ADP polymerase over-stimulation leading to a decrease in $\mathrm{NAD}^{+}$as well as in ATP concentration and leads to the activation of apoptotic program that destroys beta-cells and all the cells expressing the GLUT2 transporter (cells from the kidney and liver). By performing a bibliography research using the database MEDLINE (PUBMED) and the following keywords: "diabetes" and "alloxan" or "streptozocin" and "neuropathy" during the last 30 years (i.e. 1982 to 2012), 298 studies used the antimicrobial agent STZ and only 48 used ALX to induce diabetes. During the last 10 years (i.e. 2002 to 2012) the ratio ALX: STZ was 9: 139 probably due to the poor specificity of alloxan compared to STZ against pancreatic beta-cells. Indeed STZ generally produces greater cytotoxicity due to its conversion to anionic radicals.

STZ is more commonly used because of its greater stability and relative lack of extrapancreatic toxicity [22]. Thus, we focused our review on STZ-induced diabetic neuropathy in rodents.

\section{Clinical signs of STZ-induced diabetes in rats}

After STZ administration, hyperglycemia and hypoinsulinemia appear in the first days and persist, attesting to an irreversible toxicity. A halt in weight growth and sometimes even a weight loss are also observed [7]. Hyperglycemia is concomitant with polydipsia (water intake 10-times higher), polyuria and polyphagia [23]. While most morphological, histological and electrophysiological studies show that diabetic neuropathy is accompanied by nerve structural changes (segmental demyelination and axonal degeneration) and functional changes (assessed by nerve conduction velocity) in diabetic patients [10], structural changes are rarely reported in STZ-induced diabetic rats or appear slowly and later. Walker et al. [24] using tibial nerve biopsies from diabetic rats reported the lack of abnormal nerve tissue regarding the distribution of unmyelinated axons, diameter of myelinated axons, fascicular area, absence of Wallerian degeneration. However, abnormalities in the structure of endoneural capillaries presented increased luminal surface and decreased endothelial cells size, related to impairment in vaso nervorum. Therefore, in this experimental model, there is no structural support for the functional abnormalities, and changes in pain sensitivity.

In the absence of segmental demyelination and axonal degeneration that characterizes human diabetic neuropathy, the diabetic rat model of STZ could be considered as a short duration model of hyperglycemia in which functional abnormalities reflect early stages of diabetic neuropathy.

\section{Etiopathogenic factors of STZ-induced neuropathy}

The involvement of chronic hyperglycemia in the development and aggravation of T1DM complications in humans has been confirmed by a North American multicentric study (Diabetes Control and Complications Trial Research Group, 1993) performed on 1441 patients followed during 6.5 years. In this study, the prophylactic importance of glycemic control on the progression of retinopathy (34-76\% reduction), microalbuminuria (50\%) and neuropathy (60\% reduction) was further supported. Etiopathogenic factors of sensory neuropathy are still unclear but hypothesis coming from experimental work on diabetic rats were made. Several mechanisms underlying glucotoxicity on peripheral nerve fibers have been proposed [25]: an enzymatic mechanism involving the polyol pathway, proteins glycation and expression of advanced glycation end products receptors, as well as oxidative stress.

Glucose uptake by Schwann cells of nerves is independent of insulin: glucose enters and accumulates in neurons initiating the aldose reductase pathway. This metabolic pathway leads to the accumulation of sorbitol and fructose, to the depletion of myo-inositol and compromises glutathion cycle and ATPase $\mathrm{Na}^{+} / \mathrm{K}^{+}$activity. Inhibitors of aldose reductase, that are very efficient on functional impairment due to diabetes in rats, are much less efficient in diabetic patients, a difference probably related to the importance of the polyol pathway in rodents compared to humans.

Hyperglycemia also induces a non-enzymatic glycation of proteins, glycation end products in turn activate the transcription factor NFKB responsible for the modification of many genes expression.

Finally, excess of glucose in neuron is responsible for the increase of oxidative stress by combining free radical genesis and inefficient antioxidant protection systems. Most $\mathrm{ROS}\left(\mathrm{O}_{2}^{\circ}-, \mathrm{OH}^{\circ}, \mathrm{H}_{2} \mathrm{O}_{2}\right)$ are produced by the mitochondrial respiratory chain; NADPH oxidase and xanthine reductase, as well as reactive species of nitrogen (nitric oxide NO, peroxynitrite, ONOO-) produced by the NO synthesis enzyme NO-synthase, have been shown to be involved in the development of diabetic peripheral neuropathy in STZ-treated rat. In STZ rats, it was shown that free radicals exerted their deleterious effects on Schwann cells. Chain reaction neutralization generated by ROS is assessed by superoxydismutase (SOD), catalase and glutathione peroxidase. Thus treatment of STZ rats with antioxidants not only prevents or suppresses functional impairment [26], but also the pain-related behaviors [27]. Conversely, treatment of healthy rats with a pro-oxidant agent (premaquine) induces functional changes similar to those observed after induction of diabetes [28].

Some signaling pathways involving the MAPKinases are activated in sensory neurons exposed to increased glucose in vitro and in vivo in rats and humans with diabetes [29].

\section{Hypersensitivity in STZ-induced diabetic rat}

Behavioral studies assessed in STZ-diabetic rats often focus on their response to nociceptive or non-nociceptive stimuli, because of the absence of quantifiable signs of spontaneous pain. These tests consist in measuring time latency or withdrawal thresholds of an animal whose paw or tail is exposed to a thermal, mechanical or tactile stimulation. The place preference test, where the animal can chose between two temperatures [30] presents the advantage of getting rid of animal handling, therefore allowing the assessment of spontaneous behavior towards a range of thermal stimuli, leaving the animal free to stand on one of the 
two plates of different temperatures. Using this test has allowed to reveal a thermal hypersensibility (for a temperature of $45^{\circ} \mathrm{C}$ ) in STZ rats [31]. However, thermal hyperalgesia towards hot temperatures is not a common painful symptom in diabetic patients, which makes difficult the extrapolation of these results toward clinic [32]. Some authors, using the thermal ramp test that consists in placing the animal on a surface which temperature increases of $1^{\circ} \mathrm{C} / \mathrm{sec}$ from $30^{\circ} \mathrm{C}$ to $50^{\circ} \mathrm{C}$, have also observed hypersensitivity during the first few weeks of diabetes but that transforms into a hypoalgesia 2 to 3 month later, signing an evolution of the painful neuropathy toward an insensitive neuropathy towards nociceptive hot stimuli, that can be found in humans [33]. Moreover, a loss in thermal nociceptors was reported in diabetic patients [34].

The perception of tactile stimuli (light touch) and mechanical (pressure) is also affected by diabetes. In STZ rats, the application of a von Frey filament, producing a light static touch, causes a paw withdrawal induced by the inappropriate activation of $\mathrm{A} \delta$ and $\mathrm{C}$ fibers, signing a tactile allodynia. More recently, cotton swabs or brushes have been used to measure dynamic tactile allodynia by caressing the plantar surface of the hind paw of the animal, which evokes a paw withdrawal if $A \beta$ fibers are impaired. The comparison of the two different symptoms reveals that dynamic allodynia has a later onset than static allodynia and both painful symptoms worsen over time in STZ rats [35]. This observation suggests that the presence of dynamic allodynia results in more severe nerve damage than when static tactile allodynia is only symptom. The STZ-induced diabetic rat model makes it possible to test the dynamic tactile allodynia, which, unlike the static allodynia and thermal hypersensitivity to hot temperatures, is a common symptom of neuropathic pain in humans. The use of von Frey filaments can also be exploited for the exploration of mechanical hypersensitivity: the application of a von Frey filament (\# 4.93) exerting a very static pressure point, results in a two fold increase of the intensity of the response in diabetic animals [36].

The search for a chemical sensitivity in diabetic rats, that could, at best, mimic human inflammatory hypersensitivity observed in clinic, revealed an increase in the tonic response while the phasic response is not altered by the chemical agent [37].

\section{Pathophysiology of STZ-induced neuropathic pain}

Pain associated with nerve damage from diabetes initially involves peripheral mechanisms causing sensory fibers hypersensitivity, which secondarily leads to central rearrangements responsible for central nociceptive system hyperexcitability. In this section, we discuss the main peripheral and central mechanisms of diabetic neuropathic pain proposed by the work using the STZ-rat model.

Peripheral changes: Involvement of voltage-dependent calcium channels Cav: The T-type Cav channels ("LVA" low voltage activated) or $\mathrm{Ca}_{\mathrm{v}} 3.1,3.2$ and 3.3 are localized in cell bodies and dendrites of primary afferent fibers, and play an important role in modulating the neuronal excitability [38]. Their involvement in the pathophysiology of neuropathic pain has also been demonstrated, particularly in models of diabetes and traumatic neuropathies by sciatic nerve ligation, where current density of type $\mathrm{T}$ is greatly increased [36]. The "knockdown" strategy by $\mathrm{Ca}_{\mathrm{v}} 3.2$ isoform antisense but not the $\mathrm{Ca}_{\mathrm{v}} 3.1$ or $\mathrm{Ca}_{\mathrm{v}} 3.3$ isoforms, suppresses thermal (Hargreaves test) and mechanical hypersensitivity (applying a von Frey filament \# 4.93) in STZ-diabetic rats. Electrophysiological recording from small cells (C fibers) of dorsal root ganglia (DRG) and spinal cord (whole cell voltage-clamp) shows that the same strategy inhibits the "up-regulation" of T-type currents induced by diabetes [39].
Finally, over expression of the $\alpha 2 \delta$ subunit of L-type calcium channels belonging to the family of "HVA" (high activation threshold) in the DRG of diabetic rats is contemporary with the development of tactile allodynia appreciated by the test of von Frey filaments [40]. This $a 2 \delta$ subunit is also the pharmacological target of certain antiepileptic drugs such as gabapentin and pregabalin.

Involvement of voltage-dependent sodium channels $\mathrm{Na}_{\mathrm{v}}$ : Peripheral nerve injury can alter the expression and function of $\mathrm{NaV}$ channels a subunits which results in a change in neuronal excitability [41]. Hong et al. [42] have shown that four weeks after induction of diabetes by STZ in rats, the $\mathrm{Na}_{\mathrm{v}}$ currents sensitive ( $\mathrm{S}$ ) and resistant (R) to tetrodotoxin (TTX) increased in small diameter DRG. Quantification by Western blotting of different types of sodium channels showed an increased expression of $\mathrm{Na}_{\mathrm{V}} 1.3$ and NaV1.7 (TTX-S) channels and a decreased expression of NaV1.6 (TTX-S) and NaV1.8 (TTX-R) channels in DRG of diabetic rats (four weeks post-STZ). These authors also reported that phosphorylation of Thr / Ser residues of $\mathrm{Na}_{\mathrm{v}} 1.8$ and $\mathrm{Na}_{\mathrm{v}} 1.6$ channels, and Tyr residues of $\mathrm{Na}_{\mathrm{v}} 1.7$ and $\mathrm{NaV} 1.3$ channels is increased by diabetes. This fact is not unambiguous: while an increase and a decrease in $\mathrm{Na}_{\mathrm{v}} 1.3$ and $\mathrm{Na}_{\mathrm{v}} 1.8$ channels expression (mRNA and protein) respectively, have already been found, the expression of $\mathrm{Na}_{\mathrm{v}} 1.6$ (mRNA and protein) has been shown to increase [43]. Sensitive or resistant TTX Na channels play an important role in the pathophysiology of neuropathic pain of all etiologies, including diabetic, by changing the electrical properties of the membrane, thus contributing to the genesis of ectopic discharges. These channels are also the target of different molecules (tricyclic antidepressants, anticonvulsants, local anesthetics ...) which therapeutic efficacy in the treatment of neuropathic pain is established.

Involvement of Transient Receptor Potential (TRP) channels: Thermal sensitivity observed in STZ-treated animals [31] is probably due to the sensitization of cutaneous nociceptors associated with $A \delta$ and C fibers. TRPV1 channel (Transient Receptor Potential Vanilloid type 1), is a major actor in thermal sensitivity, predominantly present in C fibers and, to a less extent, in A $\delta$ fibers [44-46]. TRPV1 is a non-selective calcium/sodium-permeable channel activated by temperatures up to $43^{\circ} \mathrm{C}$, capsaicin (extracted from red pepper), protons $(\mathrm{pH}<5.9)$, metabolites of arachidonic acid ... ; TRPV1 can be sensitized by phosphorylation, by prostaglandins, bradykinin, glutamate, histamine, serotonin, ATP or NGF. Any change in TRPV1 expression, associated with changes in intracellular signal transduction, may lead to spontaneous neuronal activity induced by normal body temperature; this is the case if the response threshold of TRPV 1 is lowered below $38^{\circ} \mathrm{C}$ [47]. Pabbidi et al. [45], reported an increase in the amplitude of TRPV1 currents induced by capsaicin in STZ-induced hyperalgesic mice compared to STZ-induced hypoalgesic mice or normoglycemic control mice. The expression of TRPV1 channels in A $\delta$ and C fibers of STZ-treated mice was increased in those presenting hyperalgesia, and reduced in hypoalgesic mice. The same team also showed that thermal hypersensitivity developed by diabetic wild-type mice is abolished when the gene coding for TRPV1 channel is disabled (TRPV $1^{-/}$mouse). Finally, treatment with anti-vanilloid VR1 receptor antiserum abolishes thermal hyperalgesia in STZ-treated mice [44]. In physiological conditions, it was shown that insulin positively modulates the activity and expression of TRPV1 channels via protein kinase C (PKC) [48]. It is therefore possible that the sudden decrease in insulin levels induced by STZ is indirectly responsible for a decreased in TRPV1 activity, which would lead to a compensatory increasing of the expression of these channels. This could explain the thermal hypersensitivity appearing in the third 
week of diabetes in our study [31]. Another hypothesis brought by Pabbidi et al. [48] suggests a direct action of STZ onto sensory neurons, involving the ROS-p38 MAPkinase pathway, thereby altering expression and function of TRPV1. However, a direct effect of STZ on the expression and / or functionality of TRPV1 can be excluded because we have shown that animals which failed to develop hyperglycemia after STZ injection did not present thermal sensitivity disorders (unpublished results).

On the other hand, a second TRP channel, TRPA1 (Transient Receptor Potential Ankyrin type 1) seems to be involved in DPN, since some studies showed that TRPA1 antagonists changed mechanical thresholds in STZ-treated rat $[49,50]$. Moreover, the TRPA1 channel can be activated in sensory neurons by ROS, alkenyl aldehydes and 15-deoxy-prostaglandin $\mathrm{J}_{2}$, which are generated during oxidative stress leading to intracellular calcium rise [51,52]. Hence, TRPA1 receptor through indirect activation by metabolites from oxidative stress seems to be an important molecular protagonist in mechanical hypersensitivity of DPN.

Involvement of $\mathrm{HCN}$ channels: Described for the first time in pacemaker cells of the heart sinus node [53], HCN (hyperpolarizationactivated cyclic nucleotide-gated cation) channels were discovered in neurons and responsible for Ih currents [53]. HCN channels open when the membrane is hyperpolarized ( -60 to $-50 \mathrm{mV}$, i.e. to the rest potential) and generate a mixed $\mathrm{Na}^{+}, \mathrm{K}^{+}$cationic current. Four genes coding for HCN channels have been identified (HCN1-4). The most abundant in neurons of DRG are the HCN1/2 type. The Ih current generated is of greater amplitude, faster and more frequent in neurons of large and medium diameter (type A) than in small diameter neurons (type C). The administration of a HCN channel blocker, the ZD7288, suppresses tactile allodynia in STZ-induced diabetic rats (three weeks post-STZ) and reduces mechanical hypersensitivity as well (personal results), whereas ivabradine, a more selective blocker of HCN channels, suppresses cold allodynia in a model of toxic neuropathy induced by oxaliplatin [54].

Together, these data obtained in diabetic rats underline the important role played by ion channels in the balance of the neuronal membrane and the importance of any change in expression levels or thresholds of activation of these channels on the excitability of sensory fibers and their deleterious effects on nociception.

\section{Central changes}

Involvement of N-Methyl-D aspartate (NMDA) receptors: In vivo analgesic effects of dizocilpine, memantine or D-CPP, NMDA receptor non-competitive and competitive antagonists respectively, on mechanical hypersensitivity in STZ rats [55-57] can also be obtained in human clinical studies with ketamine, but they unfortunately induce debilitating side effects [58], which compromise their clinical use. NMDA receptor phosphorylation would be involved in the development of tactile allodynia, mechanical and thermal hypersensitivity [23]. Our team has also shown the importance of the specific activation of certain isoforms of MAPKinases in painful hypersensitivity in STZ animals, as well as the need for NMDA receptor activation for the phosphorylation of these kinases [59], opening new prospects for a more targeted drug therapy, thus better tolerated for diabetic neuropathic pain.

Alteration of descending systems: One of the pathophysiological mechanisms involved in the pathogenesis of chronic pain including neuropathic pain, is a loss of the inhibitory role of serotonin on persistent pain, as evidenced by (i) the nearly ineffectiveness of selective serotonin reuptake inhibitors (SSRIs) in neuropathic pain patients [60] and, (ii) results obtained in STZ-induced diabetic rats showing an alteration of spinal $5-\mathrm{HT}_{2 \mathrm{~A}}$ receptor-mediated analgesic effect, usually involved in the analgesic effect of serotonin [31]. These receptors have the particularity to be associated with specific multiprotein complexes, consisting in part of proteins containing PDZ domains, which can modulate signal transduction of receptors to which they are associated [61]. In STZ rats, the administration of a cell-penetrating peptidyl mimetic of the 5- $\mathrm{HT}_{2 \mathrm{~A}}$ receptor C-terminus ending, which disrupts their interaction with PDZ proteins, induces antihyperalgesic effect per se and enhanced the analgesic effect of fluoxetine, an SSRI [31]

Most of peripheral and central abnormalities in the transmission and modulation of nociception that have been described in STZ rats and were also found in other neuropathic pain models, especially traumatic peripheral nerve injury (CCI or SNL) showing the lack of specificity of the model. It would be simplistic to want to associate a pathophysiological mechanism to an etiology because the same mechanism can be found in neuropathies of different etiologies [62], and a given injury may involve several mechanisms.

\section{Activity of reference drugs}

$\mathrm{Ca}_{\mathrm{v}}$ channels $\boldsymbol{\alpha}_{2} \boldsymbol{\delta}$ subunit ligands: The antiallodynic and analgesic efficacy of pregabalin [63] and gabapentin [55], whose action depends on binding to the $\alpha_{2} \delta-1$ subunit of the $\mathrm{Ca}_{\mathrm{v}} 2$.X, has been shown in many neuropathic pain models, including STZ-induced diabetic rat. The increased expression of mRNAs encoding subunits $\alpha_{2} \delta$ of neurons of small (C fibers) and medium $(\mathrm{A} \delta)$ caliber in diabetic rats has been known for a decade [40] and would play a major role in the development of pain hypersensitivity.

N-type $\mathrm{Ca}_{\mathrm{v}}$ channel $\left(\mathrm{Ca}_{\mathrm{v}} 2.2\right)$ blockers: Leconotide and ziconotide, synthetic versions of $\omega$-conotoxins MVIIA and CVID produced by marine mollusks, showed dose-dependent analgesic activity after intravenous administration in the diabetic neuropathic pain model, on thermal hyperalgesia [64]. However, only the intrathecal route of administration of ziconotide is effective in patients suffering from severe chronic pain, emphasizing the difficulties and precautions needed when extrapolating data obtained from animal experiments to human disease.

$\mathrm{Na}_{\mathrm{v}}$ channel blockers: $\mathrm{Na}_{\mathrm{V}}$ channels are the target of many analgesics. Topical lidocaine (patch form), prescribed for the treatment of postherpetic neuropathic pain, is one of the most used sodium channel modulator in human therapeutics. Its analgesic activity when systemically administrated had been reported in the model of diabetic neuropathy $[37,65]$. Having a similar structure, mexiletine showed anti-allodynic activity during the early stages of experimental diabetes (three weeks post-STZ) [63], suggesting a reorganization of sodium channels along diabetes.

Antidepressants: Literature which report the analgesic effect of antidepressants in animal models are numerous and heterogeneous. We have recently stressed out the importance of using protocols of administration similar to those used clinically (repeated administration every half-life time) for assessing the effects of antidepressants [66]. Using chronic treatment, we have highlighted a differential profile of activity of milnacipran (a SNRI) depending in the etiology of neuropathy, and proposed selection criteria to use dual monoaminergic antidepressants based on their opioidergic mechanism: such mechanism would be predictive of modest efficacy, regardless of the neuropathy etiology [66]. Other experimental works in animal models, based on compara- 
tive studies of the mechanism of action of antidepressants according to the etiology and symptomatology of neuropathic pain, are necessary before initiating clinical trials; those clinical trials will be useful to test whether semiologic profiles of responders or nonresponders to a particular antidepressant may be considered as selection criteria, source of personalized treatment and thus improved efficiency.

Despite the relative lack of pathophysiological specificity of the diabetic model, pharmacological data showed particular activity profiles of analgesics that are considered to be efficient in this painful context, and made possible recommendations to improve the clinical relevance of the model.

When one considers that the predictability of a model refers to its symptoms and its sensitivity to pain treatments recognized as effective in a painful context, the experimental model of diabetic neuropathy induced by STZ can be considered as predictive, bearing in mind that the spontaneous pain has never been quantified in this model, probably because of the lack of appropriate behavioral tools. Improvement of its clinical relevance is still necessary and may come from a standardization of procedures regarding the selection of the animal (strain, age, sex, breeding), the chronicity of the disorder, the pain measurement (operative and non operative testing) [67], or on how to use pharmacological tools.

\section{Type 2 Diabetes Model in Rodents}

Type 2 diabetes (T2DM) is the most representative form of diabetes mellitus in adult diabetic population. T2DM has affected 285 million people worldwide in 2010 [68], and will probably affect more than 366 million in 2030 [69]. T2DM is characterized by an impairment of insulin actions caused by insulin secretory defects and/or peripheral insulin resistance. Peripheral insulin resistance is compensated by increasing insulin secretion which leads to reduced pancreatic beta-cell (insulinopenia) functions through local inflammatory processes which drive to increase again glycaemia [70]. The prevalence of DPN is higher in type $2(50.8 \%)$ than in type 1 (25.6\%) diabetic patients; the prevalence of painful DPN is $14 \%$ which, again, is higher in type $2(17.9 \%)$ than in type $1(5.8 \%)$ patients [17]. Nevertheless, only few studies focused their efforts to develop correct rodent model for investigating of T2DMinduced neuropathy and develop new strategies against peripheral neuropathy. A PUBMED search with "type 1 diabetes neuropathy " finds 2349 matches which have been published between 2012 and 1964 whereas a search with " type 2 diabetes neuropathy rat " or "type 2 diabetes neuropathy mice » finds 32 and 41 matches respectively which have been published between 2012 and 1988. In this sense, we have selected for this review 29 articles, which explored pain behaviors, pain thresholds and/or nerve conduction velocity in T2DM-induced neuropathy (Table 1 and 2).

\section{Obese models of T2DM}

In rat almost $50 \%$ of articles worked in the Zuker Diabetic Fatty model (ZDF), a useful and well-known model of leptin receptor gene deficiency, which displays hyperphagia, fat overstorage, glucose intolerance, hyperglycemia, glucosuria, and polyuria. Authors using this model reported tactile allodynia, mechanical and thermal hyperalgesia and a decrease in nerve conduction velocity [71-75]. In ZDF rats, the number of sural axons is preserved, but atrophy and a loss of largecaliber dermal and small-caliber epidermal axons are observed [71]. Otto et al. [73] recently showed a temporal loss of opioid sensitivity in these animals and a marked morphine hyposensitivity was evident at six months. Romanovsky et al. [74] also showed that the compensation of hyperinsulinemia might not restore compromised nerve function. On the other hand, Li et al. [72] showed that a $2 \%$ taurine diet reverses mechanical hypersensitivity and neurovascular deficits. Eventually, Sugimoto et al. [75] showed that ZDF animals also exhibited progression from thermal hyperalgesia to hypoalgesia, which occurred more rapidly and coincided with a rapid decline in pancreatic insulin secretion.

The same model of obesity and T2DM is available in mice since $o b / o b$ and $d b / d b$ models, which display leptin and leptin receptor deficiency respectively, have been developed. These models are often used for the assessment of T2DM-induced neuropathy in mice. The most obvious characteristic of leptin-deficient $o b / o b$ mice is that they are grossly overweight and have higher food consumption. They are also hyperglycemic, hyperlipidemic, hyperinsulinemic and display lowered physical activity [76]. $\mathrm{Db} / \mathrm{db}$ mouse is the most widely used model for the study of T2DM neuropathy in mice. First described in 1966, the $d b$ gene encodes a G-to-T point mutation to the leptin receptor, which is transmitted in an autosomal recessive fashion. This defect leads to the development of hyperphagia, obesity, hyperlipidemia, hyperinsulinemia, insulin resistance, and diabetes [77].

Ob/ob mice [78-80] and $d b / d b$ mice [81-83] develop thermal hypoalgesia, tactile allodynia and a decrease in nerve conduction velocity. $\mathrm{Ob} / \mathrm{ob}$ mice developed manifest sciatic motor nerve conduction velocity (MNCV) and hind-limb- digital sensory nerve conduction velocity (SNCV) deficits, thermal hypoalgesia, tactile allodynia, and a remarkable loss of intraepidermal nerve fibers [80]. In this mice, administration of fidarestat, an aldose reductase inhibitor, was associated with preservation of normal MNCV and SNCV, alleviation of thermal hypoalgesia and decreasing of intraepidermal nerve fiber loss, but not tactile allodynia [78]. Sciatic nerves of wild type C57BL6, ob/ob, and $d b / d b$ mice were investigated by electronic microscopy, which revealed injuries in myelin sheaths in small $(<5 \mu \mathrm{m})$, medium-sized $(5-10 \mu \mathrm{m})$, and large axons $(>10 \mu \mathrm{m})$ of $d b / d b$ mice compared with wild type mice. In $o b / o b$ mice, only large fibers showed a decrease in myelin sheath thickness. Moreover, the basement membranes of endoneural microvessels were thickened in both obese groups. The authors also explored laminin expression by western blot and showed a decrease in $\mathrm{db} / \mathrm{db}$ group but not in $o b / o b$. Hence, changes in nerve fibers and in endoneural microvessels are present in sciatic nerve of both mouse models [79]. Gene expression changes in $d b / d b$ mice are consistent with structural changes of axonal degeneration and interestingly Nerves Growth Factor (NGF), Substance P (SP), and calcitonin gene-related peptide (CGRP) are up-regulated in dorsal root ganglion (DRG) of $\mathrm{db} / \mathrm{db}$ mice before or during the development of mechanical allodynia [84]. Interestingly, upregulation of NGF coincided with enhanced tyrosine kinase A (TrkA) receptor phosphorylation in DRG. Further study aimed to identify the detailed mechanism of astrocyte-induced allodynia in $\mathrm{db} / \mathrm{db}$ mice. Results showed that spinal activated astrocytes dramatically increased interleukin $1 \beta$ expression which may induce the phosphorylation of NR1 subunit of NMDA on the serine residue 896 [81].

All these results show that T2DM neuropathy in obese rat and mice models could be sustained by direct injuries onto the peripheral nervous system, which involved classical molecular actors found in pain sciences. Nevertheless, these models of leptin-deficient or leptin receptors deficient obesity cannot represent a clinical reality since leptin mutation in human population still rare and, typically, people risking to develop T2DM or obesity, which could lead to T2DM have a complex 
Citation: Wattiez AS, Barrière DA, Dupuis A, Courteix C (2012) Rodent Models of Painful Diabetic Neuropathy: What Can We Learn from Them? J Diabetes Metab S5:008. doi:10.4172/2155-6156.S5-008

Page 6 of 11

\begin{tabular}{|c|c|c|c|c|c|c|c|c|c|}
\hline Animals & Strains & Model & Regimen & Age & Sex & $\begin{array}{l}\text { Nociceptive } \\
\text { behavorial } \\
\text { test }\end{array}$ & $\begin{array}{l}\text { Reported pain symp- } \\
\text { toms (hyperalgesia/ } \\
\text { allodynia) }\end{array}$ & $\begin{array}{l}\text { Nerve Con- } \\
\text { duction }\end{array}$ & References \\
\hline Rat & ZDF & $\begin{array}{l}\text { Bio-Breeding Zuker } \\
\text { Diabetic Rat (BBDZR) }\end{array}$ & Rat chow & 8 months & Male & Plantar test & Thermal hyperalgesia & Decreased & $\begin{array}{l}\text { Kamiya H et al. } \\
2005\end{array}$ \\
\hline Rat & Wistar & Goto-Kakizaki & Rat chow & $\begin{array}{l}7 \text { to } 32 \\
\text { weeks }\end{array}$ & $\begin{array}{l}\text { Male and } \\
\text { female }\end{array}$ & Tail-Flick & Thermal hypoalgesia & Not done & $\begin{array}{l}\text { Ueta K et al. } \\
2005\end{array}$ \\
\hline Rat & Wistar & Goto-Kakizaki & Rat chow & 6 weeks & Male & None & None & Decreased & $\begin{array}{l}\text { Kitahara Y et al. } \\
2002\end{array}$ \\
\hline Rat & Wistar & Goto-Kakizaki & Rat chow & 18 months & Male & None & None & Decreased & $\begin{array}{l}\text { Murakawa Y et } \\
\text { al. } 2002\end{array}$ \\
\hline Rat & Wistar & Goto-Kakizaki & Rat chow & 10 weeks & Male & TailFlick & Thermal hypoalgesia & Not done & $\begin{array}{l}\text { Liepinsh E et al. } \\
2009\end{array}$ \\
\hline Rat & Long Evans & $\begin{array}{l}\text { Otsuka Long-Evans } \\
\text { Tokushima Fatty } \\
\text { (OLETF) }\end{array}$ & $\begin{array}{l}30 \% \text { Sucrose in } \\
\text { drinking water }\end{array}$ & 30 weeks & Male & None & None & Decreased & $\begin{array}{l}\text { Nakamura J et } \\
\text { al. } 1997\end{array}$ \\
\hline Rat & Long Evans & $\begin{array}{l}\text { Otsuka Long-Evans } \\
\text { Tokushima Fatty } \\
\text { (OLETF) }\end{array}$ & Sucrose feed & 2 months & Male & $\begin{array}{l}\text { Tail Flickand } \\
\text { Tail Pressure } \\
\text { Test }\end{array}$ & $\begin{array}{l}\text { Mechanical and ther- } \\
\text { mal hypoalgesia }\end{array}$ & Decreased & $\begin{array}{l}\text { Kamenov Z et al. } \\
2006\end{array}$ \\
\hline Rat & SpragueDawley & $\begin{array}{l}\text { STZ-induced type II } \\
\text { Diabetes* }\end{array}$ & $\begin{array}{l}\text { Standard rat diet } \\
\text { supplemented with } \\
10 \% \text { sucrose, } 10 \% \\
\text { lard, } 2 \% \text { cholesterol } \\
\text { and } 0,2 \% \text { cholic } \\
\text { acid }+ \text { STZ } 30 \\
\mathrm{mg} / \mathrm{kg}\end{array}$ & $\begin{array}{l}4 \text { weeks af- } \\
\text { ter induction } \\
\text { of diabetes }\end{array}$ & Male & Radian Test & Thermal hypoalgesia & Decreased & $\begin{array}{l}\text { Xiu-ying Yang et } \\
\text { al. } 2011\end{array}$ \\
\hline Rat & ZDF & ZuckerDiabeticFatty & Rat chow & 8 weeks & Male & $\begin{array}{l}\text { von Frey } \\
\text { hairs Test } \\
\text { and Plantar } \\
\text { Test }\end{array}$ & Tactile allodynia & Decreased & $\begin{array}{l}\text { Brussee V et al. } \\
2008\end{array}$ \\
\hline Rat & ZDF & ZuckerDiabeticFatty & Rat chow & 7 weeks & Male & $\begin{array}{l}\text { von Frey } \\
\text { hairs Test }\end{array}$ & Tactile allodynia & Not done & $\begin{array}{l}\text { Otto KJ et al. } \\
2011\end{array}$ \\
\hline Rat & ZDF & ZuckerDiabeticFatty & Rat chow & $\begin{array}{l}6 \text { to } 10 \\
\text { weeks }\end{array}$ & Male & $\begin{array}{l}\text { Randal- } \\
\text { Selitto }\end{array}$ & $\begin{array}{l}\text { Mechanical hyperal- } \\
\text { gesia }\end{array}$ & Not done & $\begin{array}{l}\text { Romanovsky D } \\
\text { et al. } 2008\end{array}$ \\
\hline Rat & ZDF & ZuckerDiabeticFatty & Rat chow & $\begin{array}{l}6 \text { weeks } \\
\text { after } \\
\text { diagnostic of } \\
\text { hyperglyce- } \\
\text { mia }\end{array}$ & Male & $\begin{array}{l}\text { von Frey } \\
\text { and thermal } \\
\text { stimulation }\end{array}$ & $\begin{array}{l}\text { Thermal hyperalgesia, } \\
\text { Tactile allodynia. }\end{array}$ & Decreased & Li F et al. 2006 \\
\hline Rat & ZDF & ZuckerDiabeticFatty & Rat chow & 15 weeks & Male & None & None & Decreased & $\begin{array}{l}\text { Shimoshige } Y \text { et } \\
\text { al. } 2000\end{array}$ \\
\hline Rat & ZDF & ZuckerDiabeticFatty & Rat chow & $\begin{array}{l}8 \text { to } 36 \\
\text { weeks }\end{array}$ & $\begin{array}{l}\text { Male and } \\
\text { female }\end{array}$ & $\begin{array}{l}\text { Tail Flick, } \\
\text { Randall- } \\
\text { Selitto }\end{array}$ & $\begin{array}{l}\text { Thermal hypoal- } \\
\text { gesia followed by } \\
\text { apersistent thermal } \\
\text { hyperalgesia and } \\
\text { tardive mechanical } \\
\text { hyperalgesia. }\end{array}$ & Not done & $\begin{array}{l}\text { Sugimoto K et al. } \\
2008\end{array}$ \\
\hline
\end{tabular}

*Developp by Srinivasan K et al. (PharmacolRes. 2005)

Table 1: Rat models used in T2D-induced neuropathy.

association of inherited variations at many genetic sites and are exposed to environmental stressors [85]. In this sense, few non-obese but more pertinent models of T2DM were developed but, unfortunately, they are seldom used for the study of T2DM-induced peripheral neuropathy.

\section{Non-obese model of T2DM}

The best described rat model of non-obese diabetes which does not result of single point mutation is the congenic strain Goto Kakizaki (GK). GK is a moderately diabetic rat strain that was developed by Masaei Kakizaki and Yoshio Goto by repeated inbreeding of glucose-intolerant Wistar rats over several generations. In contrast to many other rodent models of non-insulin-dependent diabetes GK rat does not exhibit hyperlipidemia nor obesity [86].

Murakawa et al. [87] showed an impairment in the blood glucose tolerance tests in GK rats, a decrease of $76 \%$ of normal MNCV, a loss of small myelinated fibers and an atrophy/loose of unmyelinated axons. On the other hand, the levels of NGF in the sciatic nerve were significantly reduced, and concomitantly, TrkA and NGFp ${ }^{75}$ receptor expression was decreased in DRG. These changes were accompanied by significantly reduced immunoreactivity for SP and CGRP in DRG neurons and sciatic nerve. Unfortunately, this interesting paper does not correlate painful thermal and mechanical thresholds with peripheral damages and impaired expression of molecular protagonists [87].

Most studies have highlighted the beneficial role of the GK model in pharmacology by testing new drugs. Ueta et al. [88] reported that GK rat presented thermal hypoalgesia and explored the anti-hypoalgic effect of T-1095, an orally active inhibitor of Na+-glucose co-transporter (SGLT). Throughout the study, T-1095 treatment significantly decreased both blood glucose and hemoglobin $\mathrm{A}(1 \mathrm{C})$ levels in the GK rat and a concomitantly reduced the thermal impairment in tail-flick test [88]. In the same manner, Kitahara et al. [89] examined the effect of long-term suppression of postprandial hyperglycemia and glycemic fluctuation in GK by nateglinide, an antidiabetic drug which stimulates the release of insulin from pancreatic beta cells. Nateglinide treatment 
Citation: Wattiez AS, Barrière DA, Dupuis A, Courteix C (2012) Rodent Models of Painful Diabetic Neuropathy: What Can We Learn from Them? J Diabetes Metab S5:008. doi:10.4172/2155-6156.S5-008

Page 7 of 11

\begin{tabular}{|c|c|c|c|c|c|c|c|c|c|}
\hline $\begin{array}{l}\text { Ani- } \\
\text { mals }\end{array}$ & Strains & Model & Regimen & Age & Sex & $\begin{array}{l}\text { Nociceptive } \\
\text { behavorial test }\end{array}$ & $\begin{array}{l}\text { Reported pain } \\
\text { symptoms } \\
\text { (hyperalgesia/ } \\
\text { allodynia) }\end{array}$ & $\begin{array}{l}\text { Nerve Conduc- } \\
\text { tion }\end{array}$ & References \\
\hline Mice & C57BI6/J & $\begin{array}{l}\text { High Fructose } \\
\text { Diet }\end{array}$ & $\begin{array}{l}\text { D12328, } 10,5 \\
\text { kcal\% fat, and } \\
\text { D12330, 58kcal\% } \\
\text { fat with corn starch }\end{array}$ & 16 weeks of diet & Male & $\begin{array}{l}\text { von Frey hairs } \\
\text { test, Tail Flick }\end{array}$ & $\begin{array}{l}\text { Thermal and } \\
\text { mechanical } \\
\text { hypoalgesia, and } \\
\text { tactile allodynia }\end{array}$ & Decreased & $\begin{array}{l}\text { Watcho P et al. } \\
2010\end{array}$ \\
\hline Mice & C57BI6/J & $\begin{array}{l}\text { High Fructose } \\
\text { Diet }\end{array}$ & $\begin{array}{l}\text { D12328, } 10,5 \\
\text { kcal\% fat, and } \\
\text { D12330, 58kcal\% } \\
\text { fat with corn starch }\end{array}$ & 16 weeks of diet & Female & $\begin{array}{l}\text { von Frey hairs } \\
\text { test, Tail Flick }\end{array}$ & $\begin{array}{l}\text { Thermal hypo- } \\
\text { algesia, Tactile } \\
\text { allodynia. }\end{array}$ & Decreased & $\begin{array}{l}\text { Obrosova IG et } \\
\text { al. } 2007\end{array}$ \\
\hline Mice & C57BI6/J & $\begin{array}{l}\text { High Fructose } \\
\text { Diet }\end{array}$ & $\begin{array}{l}\text { D12328, 10,5 } \\
\text { kcal\% fat, and } \\
\text { D12330, 58kcal\% } \\
\text { fat with corn starch }\end{array}$ & 16 weeks of diet & Female & $\begin{array}{l}\text { von Frey hairs } \\
\text { test, Tail Flick }\end{array}$ & $\begin{array}{l}\text { Thermal hypo- } \\
\text { algesia, Tactile } \\
\text { allodynia. }\end{array}$ & Decreased & $\begin{array}{l}\text { Stavniichuk R et } \\
\text { al. } 2010\end{array}$ \\
\hline Mice & C57/BL6 & $\begin{array}{l}\text { high-fat }(45 \% \mathrm{kcal} \\
\% \text { fat) diet }\end{array}$ & $\begin{array}{l}\text { 45\% kcal \%fat diet } \\
\text { D12451i }\end{array}$ & 34 weeks & Male & Radian test & $\begin{array}{l}\text { Thermal hypoal- } \\
\text { gesia }\end{array}$ & Decreased & Vincent AM 2009 \\
\hline Mice & C57BLKS/J & $\begin{array}{l}\text { Leptin receptor- } \\
\text { deficient } \mathrm{db} / \mathrm{db} \\
\text { mice }\end{array}$ & Micechow & 10-12 weeks & Male & $\begin{array}{l}\text { Beam walk, } \\
\text { Footprinting, Grid } \\
\text { walk, Rotarod }\end{array}$ & None & Decreased & $\begin{array}{l}\text { Muller KA et al. } \\
2009\end{array}$ \\
\hline Mice & $\begin{array}{l}\text { BKS.Cg- } \\
\text { m+/+Leprdb/J }\end{array}$ & $\begin{array}{l}\text { Leptin receptor- } \\
\text { deficient } \mathrm{db} / \mathrm{db} \\
\text { mice }\end{array}$ & Micechow & 24 weeks & Male & $\begin{array}{l}\text { Hind paw with- } \\
\text { drawal time and } \\
\text { Tail Flick }\end{array}$ & $\begin{array}{l}\text { Thermal hypoal- } \\
\text { gesia }\end{array}$ & Decreased & $\begin{array}{l}\text { Pande M et al. } \\
2011\end{array}$ \\
\hline Mice & C57BLKS & $\begin{array}{l}\text { Leptin receptor- } \\
\text { deficient } \mathrm{db} / \mathrm{db} \\
\text { mice }\end{array}$ & Micechow & $?$ & Male & $\begin{array}{l}\text { von Frey hairs } \\
\text { test }\end{array}$ & $\begin{array}{l}\text { Mechanical } \\
\text { hyperalgesia }\end{array}$ & Not done & $\begin{array}{l}\text { Cheng HT et al. } \\
2010\end{array}$ \\
\hline Mice & C57BLKS & $\begin{array}{l}\text { Leptin receptor- } \\
\text { deficient } \mathrm{db} / \mathrm{db} \\
\text { mice }\end{array}$ & Micechow & 10 weeks & $?$ & $\begin{array}{l}\text { von Frey hairs } \\
\text { test }\end{array}$ & $\begin{array}{l}\text { Mechanical al- } \\
\text { lodynia }\end{array}$ & Not done & $\begin{array}{l}\text { Liao YH et al. } \\
2010\end{array}$ \\
\hline Mice & $\begin{array}{l}\text { BKS.Cg- } \\
m^{+} /{ }^{+} \text {Leprdb/J }\end{array}$ & $\begin{array}{l}\text { Leptin receptor- } \\
\text { deficient } \mathrm{db} / \mathrm{db} \\
\text { mice }\end{array}$ & Micechow & 9 to 16 weeks & Male & $\begin{array}{l}\text { von Frey hairs } \\
\text { test, Dynamic } \\
\text { plantar aesthesi- } \\
\text { ometer, Plantar } \\
\text { test, Formalin }\end{array}$ & $\begin{array}{l}\text { Mechanical } \\
\text { hyperalgesia, } \\
\text { hypoesthesia in } \\
\text { second phase of } \\
\text { formalin test }\end{array}$ & Not done & $\begin{array}{l}\text { Wright DE et al. } \\
2007\end{array}$ \\
\hline Mice & C57BLKS/J & $\begin{array}{l}\text { Leptin receptor- } \\
\text { deficient } \mathrm{db} / \mathrm{db} \\
\text { mice }\end{array}$ & Micechow & 1 to 5 month & Male & $\begin{array}{l}\text { von Frey hairs } \\
\text { test }\end{array}$ & $\begin{array}{l}\text { Mechanicalhyper- } \\
\text { sensitivity }\end{array}$ & Not done & $\begin{array}{l}\text { Ren YS et al. } \\
2012\end{array}$ \\
\hline Mice & C57BI6/J & $\begin{array}{l}\text { Leptin-deficient } \\
\text { ob/ob mice }\end{array}$ & Micechow & 8 weeks & $?$ & $\begin{array}{l}\text { von Frey hairs } \\
\text { test, Radian test, } \\
\text { Hot plate test } \\
\left(55^{\circ} \mathrm{C}\right)\end{array}$ & $\begin{array}{l}\text { Thermal hypo- } \\
\text { algesia, Tactile } \\
\text { allodynia. }\end{array}$ & Decreased & $\begin{array}{l}\text { Vareniuk I et al. } \\
2007\end{array}$ \\
\hline Mice & C57BI6/J & $\begin{array}{l}\text { Leptin-deficient } \\
\text { ob/ob mice }\end{array}$ & Micechow & 6 weeks & $?$ & $\begin{array}{l}\text { von Frey hairs } \\
\text { test, Radian test }\end{array}$ & $\begin{array}{l}\text { Thermal hypo- } \\
\text { algesia, Tactile } \\
\text { allodynia. }\end{array}$ & Decreased & $\begin{array}{l}\text { Drel VR et al. } \\
2006\end{array}$ \\
\hline Mice & C57BL6 & $\begin{array}{l}\text { Leptin-deficient } \\
\text { ob/ob mice and } \\
\text { Leptin receptor- } \\
\text { deficient db/db } \\
\text { mice }\end{array}$ & Micechow & 4 months & $\begin{array}{l}\text { Male } \\
\text { and } \\
\text { female }\end{array}$ & None & None & Not done & $\begin{array}{l}\text { Nowicki M et al. } \\
2012\end{array}$ \\
\hline Mice & CD1 & $\begin{array}{l}\text { Stress-induced } \\
\text { type } 2 \text { Diabetes }\end{array}$ & Micechow & 30 days & Male & TailFlick & $\begin{array}{l}\text { Thermal hypoal- } \\
\text { gesia }\end{array}$ & Not done & $\begin{array}{l}\text { Loizzo S et al. } \\
2010\end{array}$ \\
\hline Mice & ddY-SPF & $\begin{array}{l}\text { Tsumura, Suzuki, } \\
\text { Obese Diabetes } \\
\text { (TSOD) }\end{array}$ & Micechow & 6 and 12 months & Male & $\begin{array}{l}\text { Tail pressure test } \\
\text { (Analgesymeter) }\end{array}$ & $\begin{array}{l}\text { Mechanical } \\
\text { hyperalgesia }\end{array}$ & Not done & $\begin{array}{l}\text { lizuka S et al. } \\
2005\end{array}$ \\
\hline
\end{tabular}

Table 2: Mice models used in T2D-induced neuropathy.

suppressed postprandial hyperglycemia by $50 \%$ and normalized delayed motor nerve conduction but once again, authors do not correlate these results with pain thresholds evaluation [89]. To finish, Liepinsh et al. [90] showed that mildronate, an anti-ischaemic drug, significantly decreased both the fed-and fasted-state blood glucose and the thermal hyposensitivity [90].

The GK model is the one for which pharmacological studies have been done to study T2DM-mediated peripheral neuropathy. However it appears clearly that antidepressants, anticonvulsants, as well as $\alpha 2 \delta$ ligands, which display clinical efficiency, should be investigated in this model in order to validate its clinical pertinence for the development of new analgesic compounds.

The last model used for studying T2DM induced-neuropathy is the diet-induced diabetes model. Very few article explored pain sensitivity in this model, which, nevertheless, displays neuropathic changes when animals are fed with high fat diet (HFD). This model of T2DM-induced neuropathy is exclusively caused by the dietary regimen, the most important factor associated with idiopathic neuropathy in non-diabetic human subjects [91]. In mice, two studies explored pain thresholds in HFD which led to the conclusion that the development of thermal hypoalgesia was identical in both females [92,93] and males [94]. In females, tactile allodynia was also reported, but mechanical hypoalgesia 
was only reported in males $[92,93,95]$. These studies showed the role of nitrosative stress in peripheral nerves and demonstrated the role 4-hydroxynonenal adduct, nitrotyrosine, poly (ADP-ribose) accumulation and 12/15-lipoxygenase overexpression in peripheral nerve and dorsal root ganglion neurons. Authors proposed that oxidative stress is a good target for the treatment of diabetic peripheral neuropathy.

\section{Other models}

T2DM-induced neuropathy was also studied in another models but their using still is marginal.

1) The Otsuka Long Evans Tokushima Fatty (OLETF) rat is a Cholecystokinine 1 receptor (CCK1) knockout model which allows studying the multiple CCK functions. OLETF rats are grossly hyperphagic probably due to the loss of a feedback satiety signal in the central nervous system [96]. Administration of sucrose to OLETF rats caused significant body weight increase and marked hyperglycemia. Sucrose-fed OLETF rats demonstrated significantly delayed MNCV and their thermal nociceptive thresholds is significantly decreased [97].

2) The inbred Bio-Breeding Zucker diabetic rat (BBZDR)/Wor, is a relatively emerging model of T2DM. Diabetic male BBZDR/Wor rat are homozygous for a leptin receptor gene mutation and shares genetic background of original BB strain. BBZDR/Wor rats are hyperlipidemic and hyperleptinemic, become insulin resistant, and ultimately develop hyperglycemia as well as thermal hyperalgesia [98]

3) Tsumura Suzuki Obese Diabetes (TSOD) mice, were also obtained by selective breeding of obese male mice of the ddY strain and using indices of the heavy body weight and appearance of urinary glucose [99]. Iizuka et al. [100] reported that TSOD mice develop mechanical hyperalgesia between six to twelve months old.

4) A very interesting model is the stress-induced T2DM mice model developed by Loizzo et al. [101], A post-natal psychological stress produced a series of dysmetabolic signs highly similar to mild human T2DM. Adult mice, receiving post-natal stress, display increased body weight, fasting glycaemia and increased plasma level of corticosterone and adrenocorticotropic hormone (ACTH). Mice present thermal hyperalgesia in tail-flick test and administration of naloxone prevented body overweight and abdominal overweight suggesting an involvement of the opioid system and of the hypothalamus-pituitary axis. This model of stress should be useful to study idiopathic diabetes mellitus and neuropathy induced in these conditions [101].

5) STZ-induced T2DM model was developed by Srinivasan et al. [102] in order to replicate the natural history and the metabolic characteristics of human T2DM for suitable pharmacological screening. Authors used male Sprague-Dawley rats, which were fed with HFD ( $58 \%$ calories as fat), for a period of two weeks. HFD-fed rats exhibited significant increase in body weight, basal glycaemia, and insulinemia and also presented dyslipidemia. Then, rats received an intraperitoneal injection of a low dose of streptozotocin $(35 \mathrm{mg} / \mathrm{kg})$, which produces a decline of insulin secretion and transforms prediabetes status, induced by high fat feeding, in diabetes. Hence, rats present hyperglycemia, insulinopenia, insulin resistance, and dyslipidemia as patient with an advanced T2DM [102]. From this model Xiu-ying Yang et al. [103] showed that rats which received standard chow diet supplemented with $10 \%$ sucrose, $10 \%$ lard, $2 \%$ cholesterol and $0.2 \%$ cholic acid during one month followed by intraperitoneal injection of STZ $(30 \mathrm{mg} / \mathrm{kg})$ present thermal hypoalgesia and a decrease NCV which could be relieved by salvianolic acid A, an antioxidant [103].
All these models display painful thresholds changes; nevertheless, they are still marginal and most investigations will be necessary to improve their predictability in pain research.

Nowadays, T2DM rat or mice models are not systematically used for the study of DPN, probably because none of them is yet fully characterized but also because housing, maintain and using of knockout mice or congenic strains is more problematic than the use of the T1DM model induced by STZ which, contributed to most of our knowledge in DPN in the last thirty years.

\section{Conclusion}

Rodent models of T1DM and T2DM have vastly improved the understanding of pathophysiology of diabetic neuropathic pain and the development of new therapeutics. These models do not pretend to reproduce diabetic neuropathy, as it develops in humans, but to approach it, according to the "principle of similarity" defined by Bennett [104] The conclusions from observations obtained in these models should be drawn with care and validated in more than one model or condition because diabetic patients with painful neuropathy come from a heterogenous population in terms of etiopathogenesis, clinical course of diabetes and, for some of them, co-morbidities. Cancer is one example of co-morbidity and diabetes may negatively impact both cancer risk and outcomes of treatment. Indeed several chemotherapeutic agents like cisplatin, paclitaxel, and vincristine might cause or exacerbate neuropathy [105]. The deleterious effect of paclitaxel chemotherapy on thermal nociception was observed in STZ diabetic hyperglycemic rats [106] and further support the need for development of animal models closer to clinical reality.

This literature review reaffirms the need for collaboration between clinical and preclinical research to increase the benefit of pharmacological advances, and the relevance of the work on animal models.

\section{References}

1. Treede RD, Jensen TS, Campbell JN, Cruccu G, Dostrovsky JO, et al. (2007) Neuropathic pain: Redefinition and a grading system for clinical and research purposes. Neurology 70: 1630-1635.

2. Taylor RS (2006) Epidemiology of refractory neuropathic pain. Pain Pract 6 22-26.

3. Bouhassira D, Lanteri-Minet M, Attal N, Laurent B, Touboul C (2008) Prevalence of chronic pain with neuropathic characteristics in the general population. Pain 136: 380-387

4. Bennett GJ, Xie YK (1988) A peripheral mononeuropathy in rat that produces disorders of pain sensation like those seen in man. Pain 33: 87-107.

5. Seltzer Z, Dubner R, Shir Y (1990) A novel behavioral model of neuropathic pain disorders produced in rats by partial sciatic nerve injury. Pain 43: 205-218.

6. Vos BP, Strassman AM, Maciewicz RJ (1994) Behavioral evidence of trigeminal neuropathic pain following chronic constriction injury to the rat's infraorbita nerve. J Neurosci 14: 2708-2723.

7. Courteix C, Eschalier A, Lavarenne J (1993) Streptozocin-induced diabetic rats: behavioural evidence for a model of chronic pain. Pain 53: 81-88.

8. Authier N, Gillet JP, Fialip J, Eschalier A, Coudore F (2003) A new animal mode of vincristine-induced nociceptive peripheral neuropathy. Neurotoxicology 24 797-805.

9. Van Steenwinckel J, Brisorgueil MJ, Fischer J, Verge D, Gingrich JA, et al (2008) Role of spinal serotonin 5-HT2A receptor in 2',3'-dideoxycytidine-induced neuropathic pain in the rat and the mouse. Pain 137:66-80.

10. Said G (2007) Diabetic neuropathy--a review. Nat Clin Pract Neurol 3: 331-340 11. Calcutt NA, Cooper ME, Kern TS, Schmidt AM (2009) Therapies for hypergly- 
caemia-induced diabetic complications: from animal models to clinical trials. Nat Rev Drug Discov 8: 417-429.

12. Ziegler D (2010) Textbook of diabetes: Wiley-Blackwell.

13. Daousi C, MacFarlane IA, Woodward A, Nurmikko TJ, Bundred PE, et al. (2004) Chronic painful peripheral neuropathy in an urban community: a controlled comparison of people with and without diabetes. Diabet Med 21: 976-982.

14. Halawa MR, Karawagh A, Zeidan A, Mahmoud AE, Sakr M, et al. (2010) Prevalence of painful diabetic peripheral neuropathy among patients suffering from diabetes mellitus in Saudi Arabia. Curr Med Res Opin 26: 337-343.

15. Sadosky A, McDermott AM, Brandenburg NA, Strauss M (2008) A review of the epidemiology of painful diabetic peripheral neuropathy, postherpetic neuralgia, and less commonly studied neuropathic pain conditions. Pain Pract 8: 45-56.

16. Wu EQ, Borton J, Said G, Le TK, Monz B, et al. (2007) Estimated prevalence of peripheral neuropathy and associated pain in adults with diabetes in France. Curr Med Res Opin 23: 2035-2042.

17. Van Acker K, Bouhassira D, De Bacquer D, Weiss S, Matthys K, et al. (2009) Prevalence and impact on quality of life of peripheral neuropathy with or without neuropathic pain in type 1 and type 2 diabetic patients attending hospital outpatients clinics. Diabetes Metab 35: 206-213.

18. Leiter EH, von Herrath M (2004) Animal models have little to teach us about type 1 diabetes: 2. In opposition to this proposal. Diabetologia 47: 1657-1660.

19. Roep BO, Atkinson M, von Herrath M (2004) Satisfaction (not) guaranteed: re-evaluating the use of animal models of type 1 diabetes. Nat Rev Immunol 4: 989-997.

20. Lenzen S (2008) The mechanisms of alloxan- and streptozotocin-induced diabetes. Diabetologia 51: 216-226.

21. Szkudelski T (2001) The mechanism of alloxan and streptozotocin action in B cells of the rat pancreas. Physiol Res 50: 537-546.

22. Lee JH, Yang SH, Oh JM, Lee MG (2010) Pharmacokinetics of drugs in rats with diabetes mellitus induced by alloxan or streptozocin: comparison with those in patients with type I diabetes mellitus. J Pharm Pharmacol 62: 1-23.

23. Rondon LJ, Privat AM, Daulhac L, Davin N, Mazur A, et al. (2010) Magnesium attenuates chronic hypersensitivity and spinal cord NMDA receptor phosphorylation in a rat model of diabetic neuropathic pain. J Physiol 588: 4205-4215.

24. Walker D, Carrington A, Cannan SA, Sawicki D, Sredy J, et al. (1999) Structura abnormalities do not explain the early functional abnormalities in the peripheral nerves of the streptozotocin diabetic rat. J Anat 195: 419-427. [25]

25. Tomlinson DR, Gardiner NJ (2008) Glucose neurotoxicity. Nat Rev Neurosc 9: $36-45$.

26. Cameron NE, Cotter MA, Maxfield EK (1993) Anti-oxidant treatment prevents the development of peripheral nerve dysfunction in streptozotocin-diabetic rats. Diabetologia 36: 299-304

27. Jolivalt CG, Mizisin LM, Nelson A, Cunha JM, Ramos KM, et al. (2009) B vitamins alleviate indices of neuropathic pain in diabetic rats. Eur $\mathrm{J}$ Pharmacol 612: 41-47.

28. Cameron NE, Cotter MA, Archibald V, Dines KC, Maxfield EK (1994) Anti-oxidant and pro-oxidant effects on nerve conduction velocity, endoneurial blood flow and oxygen tension in non-diabetic and streptozotocin-diabetic rats. Diabetologia 37: 449-459.

29. Purves T, Middlemas A, Agthong S, Jude EB, Boulton AJ, et al. (2001) A role for mitogen-activated protein kinases in the etiology of diabetic neuropathy. FASEB J 15: 2508-2514.

30. Moqrich A, Hwang SW, Earley TJ, Petrus MJ, Murray AN, et al. (2005) Impaired thermosensation in mice lacking TRPV3, a heat and camphor sensor in the skin. Science 307: 1468-1472.

31. Pichon X, Wattiez AS, Becamel C, Ehrlich I, Bockaert J, et al. (2010) Disrupting $5-\mathrm{HT}(2 \mathrm{~A})$ receptor/PDZ protein interactions reduces hyperalgesia and enhances SSRI efficacy in neuropathic pain. Mol Ther 18: 1462-1470.

32. Gold MS, Chessell IP, Devor M, Dray A, Gereau RWt, et al. (2006) Periphera nervous system targets: rapporteur report. In: JN Campbell, Al Basbaum, A Dray, R Dubner, RH Dworkin, CN Sang, editors. Emerging strategies for the treatment of neuropathic pain. Seattle: IASP Press: 3-36.
33. Guy RJ, Clark CA, Malcolm PN, Watkins PJ (1985) Evaluation of thermal and vibration sensation in diabetic neuropathy. Diabetologia 28: 131-137.

34. Kennedy WR, Wendelschafer-Crabb G (1996) Utility of skin biopsy in diabetic neuropathy. Semin Neurol 16: 163-171.

35. Fields HL, Basbaum Al (1999) Central nervous system mechanisms of pain modulation. In: MSBaK M, editor. Text book of Pain, 5th Edition. Churchill Livingston, Edinburgh: Elsevier Limited: 309-329.

36. Jagodic MM, Pathirathna S, Nelson MT, Mancuso S, Joksovic PM, et al. (2007) Cell-specific alterations of T-type calcium current in painful diabetic neuropathy enhance excitability of sensory neurons. J Neurosci 27: 3305-3316.

37. Calcutt NA, Jorge MC, Yaksh TL, Chaplan SR (1996) Tactile allodynia and formalin hyperalgesia in streptozotocin-diabetic rats: effects of insulin, aldose reductase inhibition and lidocaine. Pain 68: 293-299.

38. Cao YQ (2006) Voltage-gated calcium channels and pain. Pain 126: 5-9

39. Messinger RB, Naik AK, Jagodic MM, Nelson MT, Lee WY, et al. (2009) In vivo silencing of the $\mathrm{Ca}(\mathrm{V}) 3.2 \mathrm{~T}$-type calcium channels in sensory neurons alleviates hyperalgesia in rats with streptozocin-induced diabetic neuropathy. Pain 145: 184-195.

40. Yusaf SP, Goodman J, Gonzalez IM, Bramwell S, Pinnock RD, et al. (2001) Streptozocin-induced neuropathy is associated with altered expression of voltage-gated calcium channel subunit mRNAs in rat dorsal root ganglion neurones. Biochem Biophys Res Commun 289: 402-406.

41. Dickenson $A H, B e e ~ L A(2010)$ Neurobiological mechanisms of neuropathic pain and its treatment. In: J Mogil, editor. Pain 2010 - An Updated Review: Refreshe Course Syllabus: IAPS Press: 271-282.

42. Hong S, Morrow TJ, Paulson PE, Isom LL, Wiley JW (2004) Early painful diabetic neuropathy is associated with differential changes in tetrodotoxin-sensitive and -resistant sodium channels in dorsal root ganglion neurons in the rat. $J$ Biol Chem 279: 29341-29350.

43. Craner MJ, Klein JP, Renganathan M, Black JA, Waxman SG (2002) Changes of sodium channel expression in experimental painful diabetic neuropathy. Ann Neurol 52: 786-792.

44. Kamei J, Zushida K, Morita K, Sasaki M, Tanaka S (2001) Role of vanilloid VR1 receptor in thermal allodynia and hyperalgesia in diabetic mice. Eur J Pharmacol 422: 83-86

45. Pabbidi RM, Yu SQ, Peng S, Khardori R, Pauza ME, et al. (2008) Influence of TRPV1 on diabetes-induced alterations in thermal pain sensitivity. Mol Pain 4:9.

46. Rashid MH, Inoue M, Bakoshi S, Ueda H (2003) Increased expression of vanilloid receptor 1 on myelinated primary afferent neurons contributes to the antihyperalgesic effect of capsaicin cream in diabetic neuropathic pain in mice. $J$ Pharmacol Exp Ther 306: 709-717.

47. Biggs JE, Yates JM, Loescher AR, Clayton NM, Robinson PP, et al. (2008) Effect of SB-750364, a specific TRPV1 receptor antagonist, on injury-induced ectopic discharge in the lingual nerve. Neurosci Lett 443: 41-45

48. Pabbidi RM, Cao DS, Parihar A, Pauza ME, Premkumar LS (2008) Direct role of streptozotocin in inducing thermal hyperalgesia by enhanced expression of transient receptor potential vanilloid 1 in sensory neurons. Mol Pharmacol 73 : 995-1004.

49. Koivisto A, Hukkanen M, Saarnilehto M, Chapman H, Kuokkanen K, et al. (2012) Inhibiting TRPA1 ion channel reduces loss of cutaneous nerve fibe function in diabetic animals: Sustained activation of the TRPA1 channel contributes to the pathogenesis of peripheral diabetic neuropathy. Pharmacol Res 65: $149-158$.

50. Wei H, Hämäläinen MM, Saarnilehto M, Koivisto A, Pertovaara A (2009) Attenuation of Mechanical Hypersensitivity by an Antagonist of the TRPA1 Ion Channel in Diabetic Animals. Anesthesiology 111: 147-154

51. Andersson DA, Gentry C, Moss S, Bevan S (2008) Transient Receptor Potential A1 Is a Sensory Receptor for Multiple Products of Oxidative Stress. J Neurosci 28: 2485-2494

52. Nishikawa T, Edelstein D, Du XL, Yamagishi S, Matsumura T, et al. (2000) Nor malizing mitochondrial superoxide production blocks three pathways of hyperglycaemic damage. Nature 404: 787-790.

53. Jiang $Y Q$, Sun $Q$, Tu HY, Wan $Y$ (2008) Characteristics of $H C N$ channels and 
their participation in neuropathic pain. Neurochem Res 33: 1979-1989.

54. Descoeur J, Pereira V, Pizzoccaro A, Francois A, Ling B, et al. (2011) Oxaliplatin-induced cold hypersensitivity is due to remodelling of ion channel expression in nociceptors. EMBO Mol Med 3: 266-278.

55. Chen SR, Samoriski G, Pan HL (2009) Antinociceptive effects of chronic administration of uncompetitive NMDA receptor antagonists in a rat model of diabetic neuropathic pain. Neuropharmacology 57: 121-126.

56. Courteix C, Privat AM, Pelissier T, Hernandez A, Eschalier A, et al. (2007) Agmatine induces antihyperalgesic effects in diabetic rats and a superadditive

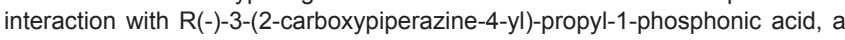
$\mathrm{N}$-methyl-D-aspartate-receptor antagonist. J Pharmacol Exp Ther 322:12371245.

57. Malcangio M, Tomlinson DR (1998) A pharmacologic analysis of mechanical hyperalgesia in streptozotocin/diabetic rats. Pain 76: 151-157.

58. Cvrcek P (2008) Side effects of ketamine in the long-term treatment of neuropathic pain. Pain Med 9: 253-257.

59. Daulhac L, Mallet C, Courteix C, Etienne M, Duroux E, et al. (2006) Diabetesinduced mechanical hyperalgesia involves spinal mitogen-activated protein kinase activation in neurons and microglia via N-methyl-D-aspartate-dependent mechanisms. Mol Pharmacol 70: 1246-1254.

60. Finnerup NB, Sindrup SH, Jensen TS (2010) Recent advances in pharmacological treatment of neuropathic pain. F1000 Med Rep 2: 52.

61. Becamel C, Gavarini S, Chanrion B, Alonso G, Galeotti N, et al. (2004) The serotonin 5-HT2A and 5-HT2C receptors interact with specific sets of PDZ proteins. J biol chem 279: 20257-20266.

62. Baron R, Binder A, Wasner G (2010) Neuropathic pain: diagnosis, pathophysiological mechanisms, and treatment. Lancet Neurol 9: 807-819.

63. Yamamoto H, Shimoshige Y, Yamaji T, Murai N, Aoki T, et al. (2009) Pharmacological characterization of standard analgesics on mechanical allodynia in streptozotocin-induced diabetic rats. Neuropharmacology 57: 403-408

64. Kolosov A, Goodchild CS, Cooke I (2010) CNSB004 (Leconotide) causes antihyperalgesia without side effects when given intravenously: a comparison with ziconotide in a rat model of diabetic neuropathic pain. Pain Med 11:262-273.

65. Courteix C, Bardin M, Chantelauze C, Lavarenne J, Eschalier A (1994) Study of the sensitivity of the diabetes-induced pain model in rats to a range of analgesics. Pain 57: 153-160.

66. Wattiez AS, Libert F, Privat AM, Loiodice S, Fialip J, et al. (2011) Evidence for a differential opioidergic involvement in the analgesic effect of antidepressants: prediction for efficacy in animal models of neuropathic pain? $\mathrm{Br} \mathrm{J}$ Pharmacol 163:792-803

67. Rice AS (2010) Predicting analgesic efficacy from animal models of peripheral neuropathy and nerve injury: a critical view from the clinic. In: J Mogil, editor Pain 2010 an updated review. Seattle: IASP Press: 415-426.

68. Federation TID (2009) Diabetes Atlas.

69. Wild S, Roglic G, Green A, Sicree R, King H (2004) Global prevalence of diabetes: estimates for the year 2000 and projections for 2030. Diabetes Care 27: 1047-1053.

70. Weyer C, Bogardus C, Pratley RE (1999) Metabolic characteristics of individuls with impaired fasting glucose and/or impaired glucose tolerance. Diabetes 48 : 2197-2203.

71. Brussee V, Guo G, Dong Y, Cheng C, Martinez JA, et al. (2008) Distal degenerative sensory neuropathy in a long-term type 2 diabetes rat model. Diabetes 57: 1664-1673.

72. Li F, Abatan Ol, Kim H, Burnett D, Larkin D, et al. (2006) Taurine reverses neurological and neurovascular deficits in Zucker diabetic fatty rats. Neurobiol of Dis 22: 669-676.

73. Otto KJ, Wyse BD, Cabot PJ, Smith MT (2011) Longitudinal study of painful diabetic neuropathy in the Zucker diabetic fatty rat model of type 2 diabetes: impaired basal G-protein activity appears to underpin marked morphine hyposensitivity at 6 months. Pain Med 12: 437-450

74. Romanovsky D, Walker JC, Dobretsov M. (2008) Pressure pain precedes development of type 2 disease in Zucker rat model of diabetes. Neurosci Lett 445: $220-223$
75. Shimoshige Y, Ikuma K, Yamamoto T, Takakura S, Kawamura I, et al. (2000) The effects of zenarestat, an aldose reductase inhibitor, on peripheral neuropathy in Zucker diabetic fatty rats. Metabolism 49: 1395-1399.

76. Lindström P (2007) The physiology of obese-hyperglycemic mice [ob/ob mice] ScientificWorldJournal 7: 666-685.

77. Tesch GH, Lim AKH (2011) Recent insights into diabetic renal injury from the $\mathrm{db} / \mathrm{db}$ mouse model of type 2 diabetic nephropathy. Am J Physiol Renal Physiol 300: $301-310$

78. Drel VR, Mashtalir N, Inytska O, Shin J, Li F, et al. (2006) The leptin-deficient (ob/ob) mouse: a new animal model of peripheral neuropathy of type 2 diabetes and obesity. Diabetes 55: 3335-3343.

79. Nowicki M, Kosacka J, Serke H, Blüher M, Spanel-Borowski K (2012) Altered sciatic nerve fiber morphology and endoneural microvessels in mouse models relevant for obesity, peripheral diabetic polyneuropathy, and the metabolic syndrome. J Neurosci Res 90: 122-131.

80. Vareniuk I, Pavlov IA, Drel VR, Lyzogubov VV, Ilnytska O, et al. (2007) Nitrosative stress and peripheral diabetic neuropathy in leptin-deficient (ob/ob) mice. Exp Neurol 205: 425-436

81. Liao YH, Zhang GH, Jia D, Wang P, Qian NS, et al. (2011) Spinal astrocytic activation contributes to mechanical allodynia in a mouse model of type 2 diabetes. Brain Res 1368:324-335

82. Muller KA, Ryals JM, Feldman EL, Wright DE (2008) Abnormal muscle spindle innervation and large-fiber neuropathy in diabetic mice. Diabetes 57: 16931701.

83. Pande M, Hur J, Hong Y, Backus C, Hayes JM, et al. (2011) Transcriptional profiling of diabetic neuropathy in the BKS $\mathrm{db} / \mathrm{db}$ mouse: a model of type 2 diabetes. Diabetes 60: 1981-1989.

84. Cheng HT, Dauch JR, Oh SS, Hayes JM, Hong Y, et al. (2010) p38 mediates mechanical allodynia in a mouse model of type 2 diabetes. Mol Pain 6: 28

85. Stumvoll M, Goldstein BJ, van Haeften TW (2008) Type 2 diabetes: pathogenesis and treatment. Lancet 371: 2153-2156.

86. Janssen U, Vassiliadou A, Riley SG, Phillips AO, Floege J (2004) The quest for a model of type II diabetes with nephropathy: the Goto Kakizaki rat. J Nephrol 17: 769-773.

87. Murakawa Y, Zhang W, Pierson CR, Brismar T, Ostenson CG, et al. (2002) Impaired glucose tolerance and insulinopenia in the GK-rat causes periphera neuropathy. Diabetes Metab Res Rev 18: 473-483

88. Ueta K, Ishihara T, Matsumoto Y, Oku A, Nawano M, et al. (2005) Long-term treatment with the $\mathrm{Na+-glucose}$ cotransporter inhibitor T-1095 causes sustained improvement in hyperglycemia and prevents diabetic neuropathy in Goto-Kakizaki Rats. Life Sci 76: 2655-2668.

89. Kitahara Y, Miura K, Takesue K, Mine T, Wada R, et al. (2002) Decreased blood glucose excursion by nateglinide ameliorated neuropathic changes in GotoKakizaki rats, an animal model of non-obese type 2 diabetes. Metabolism 51 : 1452-1457.

90. Liepinsh E, Vilskersts R, Zvejniece L, Svalbe B, Skapare E, et al. (2009) Protective effects of mildronate in an experimental model of type 2 diabetes in GotoKakizaki rats. Br J Pharmacol 157: 1549-1556.

91. Singleton JR, Smith AG, Bromberg MB (2001) Painful sensory polyneuropathy associated with impaired glucose tolerance. Muscle Nerve 24: 1225-1228.

92. Obrosova IG, IInytska O, Lyzogubov VV, Pavlov IA, Mashtalir N, et al. (2007) High-Fat Diet-Induced Neuropathy of Pre-Diabetes and Obesity Effects of "Healthy" Diet and Aldose Reductase Inhibition. Diabetes 56: 2598-2608.

93. Stavniichuk R, Drel VR, Shevalye H, Vareniuk I, Stevens MJ, et al. (2010) Role of 12/15-lipoxygenase in nitrosative stress and peripheral prediabetic and diabetic neuropathies. Free Radic Biol Med 49: 1036-1045.

94. Vincent AM, Hayes JM, McLean LL, Vivekanandan-Giri A, Pennathur S, et al (2009) Dyslipidemia-induced neuropathy in mice: the role of oxLDL/LOX-1. Diabetes 58: 2376-2385

95. Watcho P, Stavniichuk R, Ribnicky DM, Raskin I, Obrosova IG (2010) Highfat diet-induced neuropathy of prediabetes and obesity: effect of PMI-5011, an ethanolic extract of Artemisia dracunculus L. Mediators Inflamm: 268547. 
Citation: Wattiez AS, Barrière DA, Dupuis A, Courteix C (2012) Rodent Models of Painful Diabetic Neuropathy: What Can We Learn from Them? J Diabetes Metab S5:008. doi:10.4172/2155-6156.S5-008

Page 11 of 11

96. Moran TH, Bi S (2006) Hyperphagia and obesity in OLETF rats lacking CCK-1 receptors. Philos Trans R Soc Lond B Biol Sci 361: 1211-1218.

97. Kamenov Z, Higashino H, Todorova M, Kajimoto N, Suzuki A (2006) Physiological characteristics of diabetic neuropathy in sucrose-fed Otsuka Long-Evans Tokushima fatty rats. Methods Find Exp Clin Pharmacol 28: 13-18

98. Kamiya H, Murakawa Y, Zhang W, Sima AA (2005) Unmyelinated fiber sensory neuropathy differs in type 1 and type 2 diabetes. Diabetes Metab Res Rev 21: 448-458.

99. Suzuki W, lizuka S, Tabuchi M, Funo S, Yanagisawa T, et al. (1999) A new mouse model of spontaneous diabetes derived from ddY strain. Exp Anim 48: 181-189.

100. lizuka S, Suzuki W, Tabuchi M, Nagata M, Imamura S, et al. (2005) Diabetic complications in a new animal model (TSOD mouse) of spontaneous NIDDM with obesity. Exp 54: 71-83.

101. Loizzo S, Campana G, Vella S, Fortuna A, Galietta G, et al. (2010) Spampinato S. Post-natal stress-induced endocrine and metabolic alterations in mice at adulthood involve different pro-opiomelanocortin-derived peptides. Peptides 31: $2123-2129$

102. Srinivasan K, Viswanad B, Asrat L, Kaul CL, Ramarao P (2005) Combination of high-fat diet-fed and low-dose streptozotocin-treated rat: a model for type 2 diabetes and pharmacological screening. Pharmacological Research: The Official Journal of the Italian Pharmacological Society 52: 313-320.

103. Yang XY, Sun L, Xu P, Gong LL, Qiang GF, et al. (2011) Du G-H. Effects of salvianolic scid $A$ on plantar microcirculation and peripheral nerve function in diabetic rats. Eur J Pharmacol 665: 40-46.

104. Bennett GJ (2010) The logic of animal models. In: J Mogil, editor. Pain 2010 an updated review. Seattle: IAPS Press: 99-108.

105. Nicolucci A (2010) Epidemiological aspects of neoplasms in diabetes. Acta Diabetol 47: 87-95.

106. Barrière DA, Rieusset J, Chanteranne D, Busserolles J, Chauvin MA, et al. (2012) Paclitaxel therapy potentiates cold hyperalgesia in streptozotocin-induced diabetic rats through enhanced mitochondrial reactive oxygen species production and TRPA1 sensitization. Pain 153: 553-561.
This article was originally published in a special issue, Diabetic Neuropathy handled by Editor(s). Dr. Yuriy K. Bashmakov, Lycotec Ltd, Cambridge, UK 